\title{
Faith Integrity, Science, Deed and Morals Lecturer of State Polytechnic of Malang
}

\author{
Abdul Chalim \\ State Polytechnic of Malang, Jl. Soekarno Hatta no. 9 Malang, East Java, Indonesia
}

\begin{abstract}
Faith, knowledge, deed and morals are guidelines for mankind as a servant to determine the path of his life in the world and in the hereafter. Integrity is concern with action. Faith is an acknowledgment by heart, verbal pronunciation and act. Science can provide someone in better understanding on something through a way of teaching. Deed means goodness, in Islam it is stated as good deeds. Good deeds are a consequence of one's faith. Morals are interpreted as a behavior, but this behavior done continuously and not only do good deeds. Integrity, faith, knowledge, deed and morals, all of them are vital aspects for a Muslim to led us get closer to God. A Muslim who has integrity towards faith, knowledge, deed and morals means he can not only pronounce it verbally, but he must also take positive actions about faith, knowledge, deed and morals. In this discussion the author conducted a study of the fragility of faith, science, deed and morals that occur in human life. The cause of the fragility of faith, knowledge, deed and human morals can be due to environmental influences and from their own nature. Such as the environment (society), the low sense of one's faith, arrogant nature, knowledge, honesty, determination, jealousy, independence, willingness, inferiority, and the last is discipline. To become a Moslem with adequate faith, knowledge, deed and morals must come from their inner heart. Observation of parents is very important to shape the next generation within the inter connection of faith, science, deed and morals. Such as the introduction of a positive community environment, introducing religious education, introducing moral education, family approaches by teaching positive things, introducing self-potential, teaching social and religious balance, teaching responsibility for what he believes.
\end{abstract}

Keywords: Faith, Science, Deed, Morals.

DOI: $10.7176 / \mathrm{JLPG} / 86-08$

Publication date: June $30^{\text {th }} 2019$

\section{Introduction}

Faith, science, deed and morality becomes a guide to mankind, to determine the course of later life in this world and in the hereafter. Four points will be the foundation for a man as it will be defined God as a form of sincerity to Him.

The history of religion shows the happiness to be achieved by running the Islamic religion can only be done with their faith, science, deed and good morals. The belief that only form of knowledge of the oneness of God, worship is done only as a mere formality, muamalah only the rules contained in the book of course, it is not a guarantee for achieving the happiness. The progress of the community, nation and state is largely determined by the morals that develop in it. The moral character will determine the progress of human civilization which loses the dimension of divinity and humanity.

The establishment of an awareness of the integrity of faith, knowledge, deed and morals and humanity's stand on Him are the starting points that determine the pattern of human life. Moral or morality is a pattern of action based on the absolute value of goodness. Moral life and every act of immorality is the right answer to moral consciousness, otherwise life is bereft of decency, and every violation of decency is challenging awareness.

Awareness of morals is human awareness of himself, where humans see or feel themselves as a person who is faced with good and bad. That's where distinguishing halal and haram, rights and material, do's and don'ts, even though he can do it. That is a special human thing. For animals there are no good and bad or inappropriate things, because only human beings understand themselves, only humans who realize that they are dealing with their actions, before, during and after the work is done. So as subjects with actions he can account for all his deeds.

The weakness of a man's faith will make him fall into the abyss of destruction in his life, let alone caring for his fellow human beings or what we usually call deed is slowly feeling lost and starting to not be a guideline of togetherness among mankind. This is compounded by the inequality of knowledge due to the curiosity of the truth cause problems, that made human beings rely on a variety of ways to get what they want, despite the way it deviates from the teachings of religion.

\section{Integrity}

Integrity is unshakable consistency and constancy in upholding noble values and beliefs in other definitions of integrity are concepts that point to consistency between actions and values and principles. A person is said to "have integrity" if his actions are in accordance with the values, beliefs, and principles he holds. 
In short, the character of a person who has integrity is characterized by harmony in words and deeds not a person whose words cannot be held. A person who has integrity is not the type of person with many faces and an appearance that is tailored to his motives and interests.

Integrity is not just talking, but also an action. Integrity means quality, character, or condition that shows a complete unity so that it has the potential and ability that exudes authority; honesty. Someone who has personal integrity will appear full of confidence, graceful, not easily affected by things that are only for momentary pleasure. So, when talking about integrity, it is never separated from one's personality and character, namely traits such as: trustworthiness, commitment, responsibility, honesty, truth, and loyalty.

Without integrity, motivation becomes dangerous; without motivation, capacity becomes helpless; without capacity, understanding is limited; without understanding knowledge is meaningless; without knowledge, experience becomes blind.

In conclusion, integrity is a compass that directs a person's behavior. Integrity is the overall picture of one's person. The more types of people with high integrity will determine the progress of the retreat of an institution and more broadly will determine the future of a country.

\section{Faith}

Based on the hadith that relies on the statement of the angel Gabriel, the Prophet Muhammad said that faith is "you believe in Allah, to His Angels, His Books, His messengers, and believe in the Last Day, and that you must believe in the provisions or levels (Qadr) the provision of good and bad conditions ".

This is not enough just to have faith and then leave it, and also not enough just to "believe in Allah". Faith must apply also to those objects of faith and only those who believe in the faith of the whole object of one's faith is seen as the Islamic faith, not just believing in some object only.

Faith involves the belief in a true truth, not the truth of prejudice. There is no impression that a person has faith in things that are not truth. The object of their faith expresses the objective reality of things, and then they bind themselves to act on the truth they know.

The Prophet Muhammad defined the word "faith" by saying, "faith is a confession with the heart, verbal pronunciation and bodily activity". It could be said that faith involves recognition, pronunciation and deeds. The first thing to do for someone who is faithful should recognize or acknowledge a truth in his heart.

Faith is also a pronunciation of spoken or words. God Himself created this world through words. "Indeed, what we say to something if we want it to be said to us: kun (be), then be it" (16:40). God gave instructions in words through the intermediaries of the Prophets. For this reason, the entire scripture is the word of God. In fact, humanity faces God through words to Him, namely through prayer (prayer). As we know that syahadah, the first pillar of Islam and the fundamental attitude of a Muslim, is a word. Being seen is not true just by thinking that there is no god but Allah and that Muhammad is the messenger of Allah. The significance of these words is evidenced by the fact that only with words syahadah someone has been seen as a Muslim. But words are not the only requirement for faith. However, there are words of the Prophet, the faith which is the activity of the limbs. Activity is naturally governed by God, or that is in accordance with the truth of the Koran.

Islam regards the presence of faith as something that is very important. Faith involves compliance with the prescriptions of God, but obedience to God does not always include an important part of faith.

When we pledge expressed faith in Allah, means that we have promised to God. Every promise must bring responsibility and consequences. The consequences for believing in Allah SWT are many kinds and the biggest consequence is not doing shirk. Shirk is the attitude of denying or associating partners with Allah in Substance, Nature, Acts and Worship. Shirk is the biggest and most unpardonable mistake, because it means equating other than Allah with Allah, or making a rival god besides Allah. It should only be to Allah SWT we worship and ask for help. Some of the consequences of the establishment of faith, including:

- Prioritize everything that is in the sight of Allah and get rid of everything that blocks the path to the pleasure of Allah

- Loneliness yourself to accept all kinds of tests and trials in realizing that faith. Allah says:

Alif, Lam, Meem. Do the people think that they will be left to say, "We believe" and they will not be tried? But We have certainly tried those before them, and Allah will surely make evident those who are truthful, and He will surely make evident the liars. (Surah Al-'Ankabut, 29: 1-3).

- If he gets good, then he praises God and thanks Him.

- If he is hit by a disaster, is refused or delayed his desire, he intends to expect the goodness of God and be patient with His will without turning away from Him.

- Submitting (resignation), qona'ah (willing and satisfied) to all decisions of Allah SWT.

- Leaving all that is forbidden by Allah SWT and the Prophet Muhammad and carrying out His commands. In summary, faith is not enough to just confess. When we look at the consequences of the faith is the relationship between words and the heart that must be realized in life, which is deed (deeds). 


\section{Science}

Science can help someone to draw clearly through teaching. Science can be obtained through the surrounding environment or in educational institutions such as schools, colleges, universities or guidance institutions. Science is divided into two, namely academic science and non-academic sciences. The quality of life of a person is very much influenced by the knowledge they have. The higher the knowledge possessed, the greater the opportunity to improve the quality of life. Educational institutions were established to apply knowledge to the scope of work. The existence of educational institutions is expected to be able to obtain formal knowledge accompanied by proof of graduation that can be used to apply for jobs in an agency.

Schools can also be used as a means to add interaction between the members and also as a means of cultural transformation. Referred to as the transformation of culture is a continuation of the noble values that already exist in a culture that has been passed down from generation to generation so that inheritable back so that a culture can be preserved. With the knowledge gained from the educational institutions every existing technological development will be controlled properly.

Science is not just knowledge, but summarize a set of knowledge based on the theories agreed upon and can be tested systematically with a set of methods that are recognized in a given field of science. From a philosophical point of view, science is formed because humans try to think more deeply about the knowledge they have. The word science in Arabic "ilm" which means to understand, understand, or know. In regard to the absorption he said, science can mean knowledge to understand something.

Science is a human device to develop the mission of his life. In the teachings of Islam between faith and science in substantive is a unified whole. Faith and science will elevate humanity.

Muslims face the challenges of the modern world rethinking based on science and religion. To find out the true meaning of science and religion, it can be highlighted by comparing the meaning of both.

Essence of Science:

1. Science is knowledge derived from humans (human products)

2. The goal of science is exact science

3. The aim of world science is culture

4. Prediction of science based on human experience

5. The power or truth of science is relative

6. Science is focused on ability ratio

\section{Essence of Religion:}

1. Religion is knowledge originating from God

2. The goal of religion is the supernatural

3. The purpose of religion is the last day

4. Predictions of religion based on God's knowledge

5. Religious power or truth is absolute

6. Religion is spiritual power (Sidi Gazalba, 1971: 154)

Science is part of the culture and serves as the means to find the truth that is guided by religion. Science and religion coexist, cooperate accompanies human life. Islam has a strong bond with science. Prophet Mohammad in a hadith explains "Al-Science hayatul-Islam wa 'Imad'."Science is like a soul and a pillar of Islam. Even in the Koran Allah teach people to pray: My Lord, increase me in knowledge". (Surah 20: 114)

As a teaching that is Rakhmatan lilalamin, Islam encourages its people to live with knowledge. Life of a Muslim will not reach the perfection of the absence of science, or even be able to elevate human life. (Surah 58:11)

The following are the nature and function of science in Islam.

1. Science is a tool for searching for truth

2. Science as a condition of achieving transgression

3. Science is a tool for managing natural resources to achieve ridlo Allah.

4. Science as a tool for developing power of thinking.

5. Science as a result of cognitive development.

6. Faith and science lift up the degree of human life

7. The application of science in the form of scientific work is better than the blood droplets of fighters (martyrs')

Sources Science and Technology in Islam as follows:

- Al-Qur'an

- Prophet's sunnah

- Words of friends (Shahabi Madzhab)

- Human self (anfus)

- Universe

- History 
- The benefit of the people / social (Mashalil al-Mursalah)

- Traditions or customs of the people

- The thoughts of experts in Islam (Ijtihad)

- Certainly, that is, natural law existence.

Science in Islam is a means to get closer to Him.

The science is derived from education, how Islamic education brings one to truth and goodness. Education in Islamic discourse is more popular with the terms tarbiyah, ta'lim, ta'bid, riyadhah, irsyad, and tadris.

1. Tarbiyah

It means education, producing, nurturing, bearing, feeding, growing, developing, raising, and leading. Tarbiyah includes three educational domains, called as cognitive (copyright), affective (taste), and psychomotor (intention) and two aspects of education, both of physical and spiritual.

2. Ta'lim

Ta'lim means teaching. Teaching is more focused on the cognitive aspects. Ta'lim can also be interpreted as the process of transmitting various sciences to the soul of an individual without certain restrictions and conditions.

3. Ta'bid

widely refers with courtesy education, manners, adzab, character, morality, and ethics. Ta'bid introduces and guides the introduction and recognition of the power and majesty of God

4. Riyadhah

Interpreted by teaching and training, or educating the soul of a child with noble character

5. Irshad

6. tadris

Islamic education is the operational foundation that is used as a reference for realizing ideal education. The operational basis of Islamic education has six types, namely historical, sociological, economic, political and administrative, psychological, and philosophical. Religion is the last operational basis, which needs to be added to the overall operational foundation.

The function of Islamic education is to provide all facilities to enable tasks Islamic education is reached and running smoothly. In addition, it is a tool to maintain, expand and connect cultural levels, traditional and social values, and ideas of society and nation. As well as tools for change, innovation and development in outline through the knowledge and skills that have recently been found, and trained personnel productive human to find balance between social and economic change.

A knowledgeable Muslim must be a reasonable person. (Ulul Albab)

Then is he who knows that was has been revealed to you from your Lord, is the truth like one who is blind? They will only be reminded who are people of understanding. (QS. Ar-Ra'd, 13:19)

Time can be interpreted as knowledge. Anyone can get serenity, happiness, glory and secure here and the hereafter if we can give a value on it. However, this depends on how we value the time, because life simplicity is impossible to find through a shortcut.

Imam Shafi'i say if science is a must for a moslem.

Anyone who expects the world, then go by science.

Anyone who expects the Hereafter, then go by science.

\section{Deed}

For Islam, deed is refers to virtuous. Do good deed is a must for someone's faith. However, to know the conditions for the good deeds according to God's will is necessary.

Do good deeds are to carry out a good deed which is intended and hopers for the blessing from Allah. One of God's commands was to require his follower to do righteous deeds. Every Muslim is obliged to do good deeds such as:

1. Have faith in Allah

This is done by running all the commands and stay away from all prohibitions. As the word of Allah in Surah Al-Baqarah verse 197: "And take provisions, but indeed, the best provision is fear of Allah. And fear Me, O you of understanding". Here are the characteristics of believers:

a. Accept all the provisions of God

b. Istiqomah in all deeds

c. forgive the mistakes of others

d. hold trust and keep promise.

e. live life with good optimism and prejudice.

2. Birrul Walidain

It is an obligation for children to serve their parents because both of them has a lot contribution to our lives, especially mothers. It is required for us to be loyal to them. The form of devotion to both parents, includes: 
a. not saying rude to both parents

b. respect and courtesy to parents

c. don't say "ah"

d. humble and loving to parents.

e. pray for both

3. Do well to others

This is done by way of being honest, not hurt, being friendly, helping each other in goodness and piety, and others. Someone's kindness will be value, if:

a. Done with sincerity and hope for God's blessing

b. Done in accordance with the guidance of the Qur'an and Hadith

c. Done by knowing the knowledge

For a servant in doing good must be accompanied by the intention and sincerity for Allah, in accordance with the guidance of a Quran and Hadith that can bring good.

The Qur'an mentions "good deeds" in two suras, namely Al-Fatir Q.S 5:10 Q.S Attaubah: 120. The first verse revealed To Him ascends good speech, and righteous work raises it. (Q.S. Fatir: 10)

In the second verse describes the jihad in Allah's way is similar to good deeds. The verse that explains the bad deeds (gair salih) is exemplified by the insubordination of the son of Noah. (Q.S Huud: 46).

Qur'an put the word "amanu" (they believed) and "amilusshalihat" (they did good works) with the conjunction "wa" (and) in 50 verses in the Qur'an, among others: Q.S. Al-Baqarah: 25,28,82,277, Ali'Imron: 57,122,173, At-Tin: 6, Al-Bayyinah: 7, and Al-'Ashr: 3. In the other 10 verses, in surah An-Nisa ': 124, Hud: 11, Al-Isra': 9, Al-Kafh 18: 2,46, Maryam: 76, Taha: 75,122, Al -Anbiya ': 49, An-Nur: 55, Al-Qur'an also mentions the word "as-salehat" but does not connect it directly with "amanu".

From the findings above, it can be concluded that good deeds are a manifestation of faith. That is, those who believe in Allah should show faith in the form of good deeds. Faith and righteous deeds are like two sides of a coin that cannot be separated. Faith without good deeds makes it like a tree without fruit.

Thus, a believer must be running the practice of Islam, as well as people who claim Islam must declare his faith. Faith and Islam manifested in the form of good deeds which show Islamic values.

In this verse, Allah promises to those who believe and do good obtained heaven (enjoyment), forgiven (God's forgiveness), and a great reward (arjun azhim). Besides, praiseworthy deed is the key to luck in human life.

Based on some scholars the charity consists of two things, such as jariyah and worship. Jariah is a good deed that is done voluntarily by expecting the pleasure of Allah SWT, and bringing a reward for those who do it, even though he has been in the afterlife.

Charity is frequently did which leads to the path of glory, the way of the Prophets. God's messengers always give charity, and teach their people to do so. The role model of Muslims is Prophet Muhammad was known as the most generous figure. He never refused when he asked for help or favor. Jabir bin' Abdillah testified "Never once did Rasulullah SAW be asked for anything then he said no" (HR Muslim no. 2311).

In general people are tending to not do charity in hard situation. Therefore, charity in that situation, is considered as highly valued by Allah, as His word: "Let a man of wealth spend from his wealth, and whose provisions are let him spend from what God has given him. (QS Ath Thalaq: 7).

We can share whatever we have or what we can give such as reading the Koran addressed to the Prophet Muhammad, ulama, or our relatives who have passed away. The goodness of our prayer will come to them. Abu Dhar Al Ghifaryra tells that Prophet Muhammad once explained to a friend, "Hasn't God made you something that can be donated? That is, every tasbih is sadaqah, every tahmid is sadaqah, every tahlil is sadaqah, telling goodness is sadaqah, avoiding from mischief is sadaqah, and your intimate relationship with your wife is also sadaqah. "(HR. Muslim).

\section{Morals}

Morals are interpreted as behavior, which must be done repeatedly. A person can be said to be degenerate if it arises by itself driven by a strong motivation and done without much thought so impressed as a compulsion to act. If the act is carried out by force is not a reflection of morals.

Morals is also known as character, behavior or tabi'at. Ibnu Miskawaih argues that morality is a state of the soul of a person who encourages carrying out actions without going through consideration of thoughts first. Whereas according to Al-Ghazali Morals is a character embedded in the soul that triggers actions to be carried out without the need for consideration of thoughts. Ahmad Amin explained that morality is a science that explains good and bad, expresses goals that must be addressed by humans in their actions and shows the way to do what must be done.

Substantially moral is the nature of the heart that is reflected in behavior. If the nature of his heart is good then what appears is good morals, and vice versa. Moral manifestations in human life experience differences, 
this is influenced by two factors. (Thohir Luth 2005: 119-133) they are:

a. Internal factor: innate properties

b. External factors: comes from outside the human self because of an action and interaction

Morals are part of the Islamic Shari'ah, which is part of Allah's commands and prohibitions. Morals are characteristics that must be possessed by a Muslim in order to complete the practice of Islam.

Morality is a reflection of what is in the soul. Good morality is an encouragement from a person's sense of faith. Of course, faith must be manifested in daily life. Good morality is a result of synergy both from Aqeedah and Shari'a. When its connected, it will trigger a behavior that is in accordance within Shari'a.

Some things related to that are morals to God, humans and the surrounding.

1.Morality to Allah

a. Worship to Allah

b. Dhikr to Allah

c. Pray to Allah

d. Surrender to Allah

e. Obey to Allah

2. Morality to Humans

a. Morals to our self (Patient, Obey, and thankful)

b. Morality to parents

c. Morality to family

3. Morality to the surrounding

The synergy from faith, knowledge, deeds, and morals is urgent for Moslem. This way serves a straight path to get closer to Allah. Moslems is considered to have integrity in his actions that are synchronized the values, beliefs and principles.

Moslem who has integrity will acts consciously with his thoughts and actions. It will not come to perfection if some of the requirements are invalid. These four pillars become the foundation of the established faith as an effort to get intimate to God. Faith wrapped in integrity will lead to understanding science. If we are able to understand it, and keep the balance of religion and life thought, then the science will become a practice of kindness as taught by Allah and his Holy Prophet, Muhammad SAW.

In the discussion, the author highlighted some issues related on lack of faith, science, good deeds and morals in everyday life. For example, some problems emerged on fights among students, lack of manners and other deviation that are not in line to integrity of faith, science, good deeds and morals. If we still don't get a solution, what will waiting us ahead is the crisis of integrity for our future generation. Therefore, education must be taught to nurture values in order to shape the good character for our next generation.

Several factors affect the integrity of the four fundamental aspects. Some problems were mentioned as the trigger of the fragility of those four fundamental aspects, such as:

1. Environment

Environment has strong influence on how someone morals are created. If God gives punishment to people, the good one can be affected too, by God's will. Therefore, we must be aware and introspective toward the environment.

2. Lack of sense of faith.

A faith weakness is noticed by the broken morality. However, faith is the fundamental to developing morality.

3. Vanity.

As the prophet Muhammad SAW said: Pride rejects the truth, and disparages others. If someone rejects the truth, then he tried to show his ugliness. By harassing the person who conveys the truth it is a reflection of bad morality.

4. Correct knowledge

Science became the most influential factor in a person's level of moral goodness. If someone equip themselves with the right knowledge, then he should practice it. Because the consequence of science is deeds, then vice versa, if a person does not equip himself with knowledge, then he cannot distinguish between bad and good. As a fool who does not know between day and night. Wal'iyadzu billah.

5. Honesty

Dishonesty to anyone, anywhere will cause a prolonged problem, so that other problems will emerge and worsen the situation. Dishonesty in Islam and for anyone is greatly avoided, because it will lead to mistakes, if it is not stopped then the error will continue and lead to ignorance.

6. Strengthens

Firmness is needed in shaping a person to believe in taking any decision. If someone does not believe in his heart, then he will be very easily influenced, which could plunge the bad deeds. 
7. Envy

Envy is characterized by love to see other people difficult, and difficult to see other people happy.

8. Independence

Anyone is required to be independent, to avoid dependency. If the dependency reaches its limit it will trigger a disgraceful act.

9. Will

A Muslim is required to have a desire to do good things. If you do not have a strong will to do something better, then he will be missed. If this is not matched by a strong will would drag to bad attitude.

10. Inferiority

When a person feels inferior, he is unable to fulfill the various rights and obligations given to him. What happens is that he will look for excuses made in various ways such as lying, betraying or being hypocritical. Sometimes he also threw his fault to others.

11. Discipline

There are so many accidents causes by indiscipline. All existing regulations are violated arbitrarily, of course, this will lead him to harm.

\section{How to form the faith, science, charity, integrity and human morals}

To establish the integrity of Muslim faith, science, charity and morality should started from of our self. To establish the next generation within the integrity of the faith, science, deeds and morals, it requires big effort. Some ways to create the human integrity of the faith, science, charity and morals, as follows:

1. Ideal community environment

a positive environment will shape a person's right to take appropriate action with the environment. The introduction of a positive environment will foster a sense of security in the neighborhood. Also the creation of sustainable harmony.

2. Introduction to Islamic Education

The introduction of religious education has become a provision that must be accomplished by anyone. Religious education will bring someone closer to God. Through religious education will nevertheless led to a truth.

3. Introduction to moral education

Moral education will shape a person's character to be good, which aims to bring people closer to their surroundings. At the end of its sense of comfort and harmony will be created by itself

4. Family approach to teaching positive

Parents are obliged to teach good things to their children so as not to fall into the wrong life.. Here are guidelines to educate children ${ }^{1}$

a. Sound off good sayings

b.Introduce our children with daily Islamic way

c. teaches commendable attitude

d.Nurturing respect for the older and the younger people

e.Nurturing responsibility to maintain harmony and peace on the family

f. Get children deliberation in solving problems

g.Educating children to maintain friendship

h.Educate children to respect teachers

i. Educating children to shows gratitude

j. Keep away the children from the drinks and food which are prohibited

k.Encouraging and educating the children through prayer

1. Nurturing belief to Allah SWT

m. Nurturing love to God and His Prophet

n.Nurturing love to study and explore

o.Educating children to be independent

p.Educating children to respect their fellow human beings

5. Getting to know your own potential

Getting to know your potential is very important to know the strengths and weaknesses you have. So when dealing with other people can figure out what to do.

6. Teaches a balance of social and religious sciences

The balance of social science and religion must be taught to children, because through social science we get closer to our fellow humans. Through the science we are closer to Allah, His Prophet Muhammad 
SAW and as a provision to the hereafter.

7. Teach responsibility for what he believes

Responsible for what is done is a real action needed in faith, science, charity and morals. Responsible is a real action as proof of his words were true.

\section{Conclusion}

A perfection requires integrity. The process of human life in the world requires interaction and a lot of support. Here faith, knowledge, charity and morals play an important role. Therefore, in order to achieve this more dynamic and civilized human being endowed with common sense and manners, in the form of oral beliefs and actions as a process that leads man towards socialization civilized.

Faith, science, deeds and morality are the four things we need to know and understand it, because it will become the destination and way of life for mankind. Of course, if a people really explore these four they would achieve happiness in this world and in the hereafter.

Integrity involves real action. What is said must be in accordance with the action. Faith is a confession with the heart, verbal pronunciation, and activity of the limbs. Science is knowledge of a field that is systematically arranged according to certain methods, which can be used to explain the symptoms in the field of science. Science can be obtained through the surrounding environment or at schools, colleges, and universities. Charity is an act that is synonymous with goodness. Good deed it is called righteous deeds. Moral is a condition of the heart that depends on reflection of behavior. Good morals are called al-akhlaq al-karimah, while bad morals are called al-akhlaq al-mazmumah.

\section{References}

Budi Santoso, Sentot dan Zulkifli, 2013. BISMILLAH, Solo: Mutiara Kertas

Fadloli, Sri Nurkudri, Abdul Chalim, 2013. Pendidikan Agama Islam Pada Perguruan Tinggi Umum, Malang: Aditya Media Publishing

Mansur, Yusuf, 2012. DAQU Dakawh Quran di Khayalitsha, Tangerang: PPPA Daarul Qur'an

Mujib, Abdul dan Jusuf Mudzakkir, 2006. Ilmu Pendidikan Islam, Jakarta: Kencana Prenada Media

Murata, Sachiko dan William, 1997. Trilogi Islam (Islam, Iman dan Ihsan), Jakarta: Raja Grafindo

Thalib, Muhammad, 1996. 50 Pedoman Mendidik Anak Menjadi Shalih, Bandung: Irsyad Baitus Salam (IBS) 